\title{
Nerve Growth Factor Receptors on Cultured Rat Schwann Cells
}

\author{
Peter S. DiStefano and Eugene M. Johnson, Jr. \\ Department of Pharmacology, Washington University School of Medicine, St. Louis, Missouri 63110
}

Neonatal rat Schwann cells were grown in tissue culture and assayed for NGF receptors with time in culture. NGF receptor levels on freshly prepared Schwann cells (day 0 ) were low but increased dramatically during the first week in culture. Characterization of ${ }^{125}$ |-NGF binding to resuspended cells grown for $4 \mathrm{~d}$ in culture revealed that binding was not saturable at high ligand concentrations (50-70 $\mathrm{nM}$ ) and that a high-capacity, low-affinity NGF binding component existed on these cells as compared to PC12 cells. The monoclonal antibody, 192-lgG, which recognizes the rat NGF receptor, was used as an immunohistochemical tool to verify the presence of NGF receptors on the cultured rat Schwann cells. In contrast to radiolabeled NGF, ${ }^{25 \mid}$ - 192-IgG demonstrated saturable binding to Schwann cells in suspension, with $K_{\mathrm{c}}$ and $B_{\max }$ values of $4 \mathrm{nM}$ and $115 \mathrm{fmol} / 10^{8}$ cells, respectively. Schwann cells showed no evidence of slow dissociation or internalization of NGF binding at any of several NGF concentrations. 192-IgG was used to immunoprecipitate ${ }^{125}$-NGF chemically crosslinked to cell membranes. SDS-PAGE and subsequent autoradiography of the immunoprecipitated NGF receptors revealed that 2 species of NGF receptors were precipitated from Schwann cells and PC12 colls. In PC12 cells, 2 bands with molecular weights of 90 and $210 \mathrm{kDa}$ were identified. The Schwann cell NGF receptor species migrated slower on the gels, with apparent molecular weights of 95 and $220 \mathrm{kDa}$. Further analysis of glial cell NGF receptors showed that Schwann cells isolated from the vagus nerve of neonatal rats also expressed NGF receptors in culture; however, astrocytes cultured from neonatal rat cerebral cortex, cultured under conditions reported here, were devoid of detectable NGF receptors.

These results show that NGF receptor levels on Schwann cells increase with time in culture, and this resembles what is observed in Schwann cells in vivo when adult peripheral nerve is injured. The data are discussed in terms of a supportive role for the Schwann cell in facilitating peripheral nerve development and regeneration.

Received Feb. 27, 1987; revised June 15, 1987; accepted June 17, 1987.

We thank Dr. Pamela T. Manning for assistance with the immunohistochemistry of 192-IgG and anti-S-100. The authors also thank Juseph Doyle, Patricia Lampe, and Patricia Osborne for valuable assistance with tissue culture procedures and preparation of NGF and 192-lgG. This work was supported by a grant from the Monsanto Company, St. Louis, MO, and a grant from the National Institute on Aging, AHR-1-P50-AG05681 (Washington University Alzheimer's Disease Research Center).

Correspondence should be addressed to Eugene M. Johnson, Jr., Department of Pharmacology, Box 8103, Washington University School of Medicine, 660 South Euclid Avenue, St. Louis, MO 63110.

2 Present address: Neuroscience Research, Abbott Laboratories, Abbott Park, IL 60064 .

Copyright $(1988$ Society for Neuroscience $0270-6474 / 88 / 010231-11 \$ 02.00 / 0$
The tropic and trophic actions of NGF appear to be mediated by NGF receptors localized on the cell surface of NGF-dependent neurons. In peripheral sympathetic and sensory neurons, the trophic actions of NGF are initiated by the binding of NGF to specific cell-surface receptors (see review, Thoenen and Barde, 1980), followed by internalization and retrograde transport of NGF to the cell body. Exactly how NGF interacts with various organelles at the cell body to exert its trophic actions remains uncertain.

Other neurons and cell lines such as cholinergic neurons of the CNS and PC1 2 cells have been shown to bear NGF receptors and to be responsive to NGF. As with the neural crest-derived neuronal types, NGF is thought to act on these cells through specific cell-surface receptors for NGF. The binding of NGF to sympathetic and sensory neurons, PC.12 cells, and melanoma cells has been well characterized, and it is clear that different cell types bind NGF with varying affinities. In sympathetic and sensory neurons, as well as in PC12 cells, NGF binds to highand low-affinity components on the cell surface. These are designated as type I (high-affinity, slow-dissociating) and type II (low-affinity, fast-dissociating) receptors. The $K_{\mathrm{d}}$ values for the high- and low-affinity sites are approximately $10^{-11}$ and $10^{-9}$ M, respectively (see review, Buxser et al., 1985). Other cells, such as the A875 human melanoma cell line, possess only the low-affinity NGF receptors (Fabricant et al., 1977; Sherwin et al., 1981).

In recent years several reports have emerged describing specific binding of NGF to non-neuronal (or non-neuron-like) cells. Sutter ct al. (1979a) reported specific binding of NGF to the non-neuronal cells present in cultures of chick sensory neurons. Further reports have corroborated these findings (Carbonetto and Stach, 1982) and have localized the NGF binding sites to Schwann cells grown in tissue culture (Zimmerman and Sutter, 1983; Rohrer, 1985). In addition, NGF binding sites were identified on cultured human neurofibroma tumor tissues, whose cells originate from peripheral nerve ensheathments and have distinct Schwann cell-like features (Ross et al., 1984; Sonnenfeld et al., 1986). While it appears that NGF binding sites are present on Schwann cells (and possibly Schwann cell-derived tumors), the physiological significance of these receptors remains uncertain.

Recently, Taniuchi et al. (1986b) demonstrated that the NGF receptor level in the distal portion of an injured peripheral nerve increases dramatically with time after lesion. Histochemical analysis shows that the NGF receptors are located on Schwann cells in the distal nerve. These findings are discussed in the context of a supportive role for Schwann cells in the regeneration process of the injured nerve. It is proposed that Schwann cells release NGF and sequester it on the induced receptor to provide an NGF-laden substratum that would facilitate regeneration of sympathetic and sensory axons. It is well established that injured 
nerve and cultured glial cells provide good environments through which peripheral and central neurons can send axons (David and Aguayo, 1981; Fallon, 1985; Schwab and Thoenen, 1985; Kromer and Cornbrooks, 1986). It is possible that the NGF receptor on Schwann cells, induced during nerve injury, plays a crucial role in this phenomenon.

The purpose of the studies reported here was to localize NGF receptors on primary rat Schwann cell cultures and to characterize these binding sites with respect to their appearance with time in culture, binding affinity and capacity, ligand dissociation kinetics, and molecular-weight determination. Results reported here show that certain aspects of NGF binding to Schwann cells are distinct from the binding of NGF to conventional NGFresponsive cells.

\section{Materials and Methods}

Primary rat Schwann cell culture. Schwann cells were isolated from neonatal rat sciatic nerves by the method of Brockes et al. (1979), modified as follows. Right and left sciatic nerves from postnatal day 1 (P1) rats were dissected under sterile conditions and placed in L15 medium buffered with HEPES, pH 7.2. Nerves were incubated with 1 $\mathrm{mg} / \mathrm{ml}$ collagenase (Cooper Biomedical, Malvern, PA) for $1 \mathrm{hr}$ and washed with HEPES-buffered L 15 medium. The nerves were triturated with a reduced-bore pipet and plated out in Falcon T-flasks (3013) in medium containing Dulbecco's Modified Eagle's medium (Gibco, Grand Island, NY), $10 \%$ heat-inactivated fetal calf serum (Hazelton, Denver, PA), $100 \mathrm{IU} / \mathrm{ml}$ penicillin, $100 \mu \mathrm{g} / \mathrm{ml}$ streptomycin, and $1 \mathrm{~mm}$ glutamine. Cells were plated at $2-3 \times 10^{6}$ cells per flask in a volume of 5 $\mathrm{ml}$ and maintained in a humidified atmosphere of $10 \% \mathrm{CO}_{2}$ and $90 \%$ air at $37^{\circ} \mathrm{C}$. After $2 \mathrm{~d}$ in culture the cells were treated with $10^{-5} \mathrm{M}$ Ara-C for $2 \mathrm{~d}$. This treatment selectively destroyed the rapidly dividing fibroblasts in the cultures while having limited deleterious effects on the Schwann cell population. After $4 \mathrm{~d}$, the cultures were $90-95 \%$ enriched for Schwann cells as determined by visual inspection (see Fig. 1C). For longer-term cultures, normal medium was placed on the cells for $3 \mathrm{~d}$, followed by $3 \mathrm{~d}$ of treatment with Ara-C. This cycle was repeated until cells were used for assay. Schwann cells were also prepared from P1 vagus nerves, dissected from the upper thoracic region caudal to the jugular and nodose ganglia, as described above.

In one experiment, sciatic nerves were dissected from embryos and neonatal rats [embryonic day 19 (E19) to P3], dissociated, and plated as described above for P1 sciatic nerves.

Rat astrocyte cultures. Rat astrocytes were prepared from P6 rat cerebral cortices according to the method of Raff et al. (1979).

Other cell cultures. PC1 2 cells were cultured as described (Greene and Tischler, 1982). Primary cultures of rat superior cervical ganglia (SCG) were cultured as previously described (DiStefano et al., 1985).

Immunohistochemical staining of the NGF receptor and $S-100$ protein. Cultured Schwann cells, astrocytes, and SCG neurons were stained for NGF receptors by using the monoclonal antibody, 192-IgG, which recognizes only the rat NGF receptor (Chandler et al., 1984; Taniuchi and Johnson, 1985). Cells were stained for S-100 protein with a polyclonal rabbit anti-bovine S-100 antiserum. For $192-\operatorname{IgG}$ staining the cultures were grown on polylysine-coated $(0.1 \%)$ glass tissue culture slide chambers (Miles Laboratories, Naperville, IL) for various times and fixed in $1 \%$ paraformaldehyde in PBS, pH 7.2. Cultures were stained by using a mouse IgG Vectastain ABC kit (Vector Laboratories, Burlingame, CA) with glucose oxidase as the marker enzyme. The cultures were blocked with $1.5 \%$ normal horse serum for $30 \mathrm{~min}$ and $192-\mathrm{IgG}$ or a mouse myeloma protein (MOPC $21 \mathrm{IgG}_{1}$, Litton Bionetics, Inc., Charleston, SC) was added at $5 \mu \mathrm{g} / \mathrm{ml}$ for $45 \mathrm{~min}$. The cells were washed twice with PBS, and biotinylated anti-mouse IgG antibody was added for $30 \mathrm{~min}$, followed by the $\mathrm{ABC}$ reagent containing glucose oxidase (avitin-biotin complex) for $30 \mathrm{~min}$. The cells were washed with PBS, and the glucose oxidase substrate (NTB) was added. The colored reaction was allowed to proceed for 15-45 min and the cells were washed with PBS. For S-100 staining, cells were fixed with $100 \%$ ethanol for $5 \mathrm{~min}$ on ice. Staining was performed with a rabbit IgG Vectastain ABC kit basically as described above. The anti-S-100 antiserum was diluted 1:1500, as was the normal rabbit serum used in this procedure. Photomicrographs were taken with a Nikon camera (model FG) under Hoffmann optics using Kodak Ektachrome 160 tungsten film.
Ligand binding assays to whole cells. NGF and 192-IgG were radioiodinated according to the method of Marchalonis (1969). Incorporated iodine was separated from free ${ }^{125} I$ on a Sephadex $G-25$ column. Specific activities for ${ }^{125} \mathrm{I}-\mathrm{NGF}$ and ${ }^{125} \mathrm{I}-192-\mathrm{IgG}$ ranged from $1300-2200$ and $300-1800 \mathrm{cpm} / \mathrm{fmol}$, respectively. For NGF and 192-IgG binding isotherms, Schwann cells grown in culture for $4 \mathrm{~d}$ were harvested mechanically, washed twice with $0.1 \% \mathrm{BSA} / \mathrm{PBS}$, and resuspended in $0.1 \%$ BSA/PBS. On ice, $100 \mu \mathrm{l}$ of cell suspension was added to $50 \mu \mathrm{l}$ of ${ }^{125} \mathrm{I}$ labeled ligand plus $50 \mu \mathrm{l}$ of unlabeled ligand or BSA/PBS for $1 \mathrm{hr}$ for 192-IgG or $80 \mathrm{~min}$ for NGF. It was determined that equilibrium was attained when binding reactions were carried out for the times indicated for the respective ligands. Triplicate $50 \mu \mathrm{l}$ aliquots of the binding mixture were then layered over $200 \mu \mathrm{l}$ of $0.32 \mathrm{M}$ sucrose/PBS in $400 \mu \mathrm{l}$ polyethylene microfuge tubes. The tubes were centrifuged for $25 \mathrm{sec}$ in a Beckman model B microcentrifuge and quickly frozen in a dry ice/ methanol bath. The tips of the tubes containing cells with bound ${ }^{125} \mathrm{I}$ labeled ligand were cut and their radioactivity determined in a Beckman gamma counter (model 4000). The upper portion of the tubes, representing free ligand, was counted separately. Specific binding was defined as the difference in binding in the presence and absence of an excess (100- to 500-fold) of unlabeled ligand. Specific binding of ${ }^{125} \mathrm{I}-\mathrm{NGF}$ and ${ }^{125}$ I-192-IgG to cultured Schwann cells ranged from $40-81 \%$ and $60-$ $92 \%$, respectively.

For ligand dissociation studies, a fixed concentration of ${ }^{125}$ I-NGF or ${ }_{125} \mathrm{I}-192$ was added to harvested cells at $37^{\circ} \mathrm{C}$, and aliquots of the binding reaction were assayed at various times by using the centrifugation method described above. After $30 \mathrm{~min}$ of association at $37^{\circ} \mathrm{C}$ (binding at equilibrium), an excess of unlabeled ligand was added, and aliquots were assayed for binding as a function of time at $37^{\circ} \mathrm{C}$. Specific binding was determined as described above. Association-dissociation curves were generated from these data for Schwann cells and PC12 cells.

Crosslink/immunoprecipitation assay for $N G F$ receptor. This assay has been previously described in detail (Taniuchi et al., 1986a). Briefly, Schwann cells, astrocytes, or PC12 cells were incubated with 5-10 nM ${ }^{125} \mathrm{I}-\mathrm{NGF}$ for $1 \mathrm{hr}$ at $37^{\circ} \mathrm{C}$. Labeled NGF was crosslinked to its binding sites with $20 \mathrm{~mm}$ 1-ethyl-3-(3-dimethylaminpropyl)-carbodiimide $\mathrm{HCl}$ (EDAC; Pierce Chemical Company, Rockford, IL). The cells were then solubilized with $2 \%$ octylglucoside (Sigma, St. Louis), and the receptor was immunoprecipitated using $10 \mu \mathrm{g}$ of the 192-IgG antibody. This complex was pelleted by incubation with Staphylococcus aureus (Pansorbin; Calbiochem, San Diego), pre-adsorbed with rabbit anti-192-IgG. Reducing sample buffer, $100 \mu \mathrm{l}$, was added to the Pansorbin-antibodyreceptor complex, and this was chromatographed on an SDS 7\% polyacrylamide gel. The gel was subsequently exposed to autoradiographic film for receptor visualization. In certain assays, sensitive quantitation of receptor was achieved by layering the Pansorbin-antibody-receptor complex over a $0.32 \mathrm{~m}$ sucrose cushion, followed by centrifugation as described above. Specific binding was determined as described for the whole cell binding assay or by substituting a negative control antibody in the place of 192-IgG. Both methods yielded similar values.

Reagents. ${ }^{125}$ Iodine Na was purchased from Amersham (Chicago) at concentrations of $1 \mathrm{mCi} / 10 \mu \mathrm{l}$. NGF was purified from mouse submaxillary glands as described (Bocchini and Angeletti, 1969). The mouse anti-rat NGF receptor monoclonal antibody 192-IgG (Chandler et al., 1984) was prepared by a modification of a previous method (Taniuchi and Johnson, 1985). The 192-IgG from ascitic fluid was purified by using a rat anti-kappa light chain monoclonal antibody, termed 187 (Yelton et al., 1981). This antibody recognizes 192-IgG, which possesses immunoglobulin light chains of the kappa subclass. Monoclonal antibody 187 was coupled to Sepharose 4B, and the 192-IgG was purified by using standard affinity chromatography techniques. Rats used in these experiments were purchased from Chappel Breeders (St. Louis). The rabbit anti-S-100 antiserum was the kind gift of Dr. Blake W. Moore, Department of Psychiatry, Washington University School of Medicine.

All other reagents used in these experiments were of analytical quality and were obtained from commercial suppliers.

\section{Results \\ Immunohistochemical localization of NGF receptors on cultured Schwann cells}

Specific binding of ${ }^{125}$ I-NGF and ${ }^{125}$ I-192-IgG was detected on the Schwann cell cultures described in these studies (see below). To verify that the specific binding was localized to Schwann 


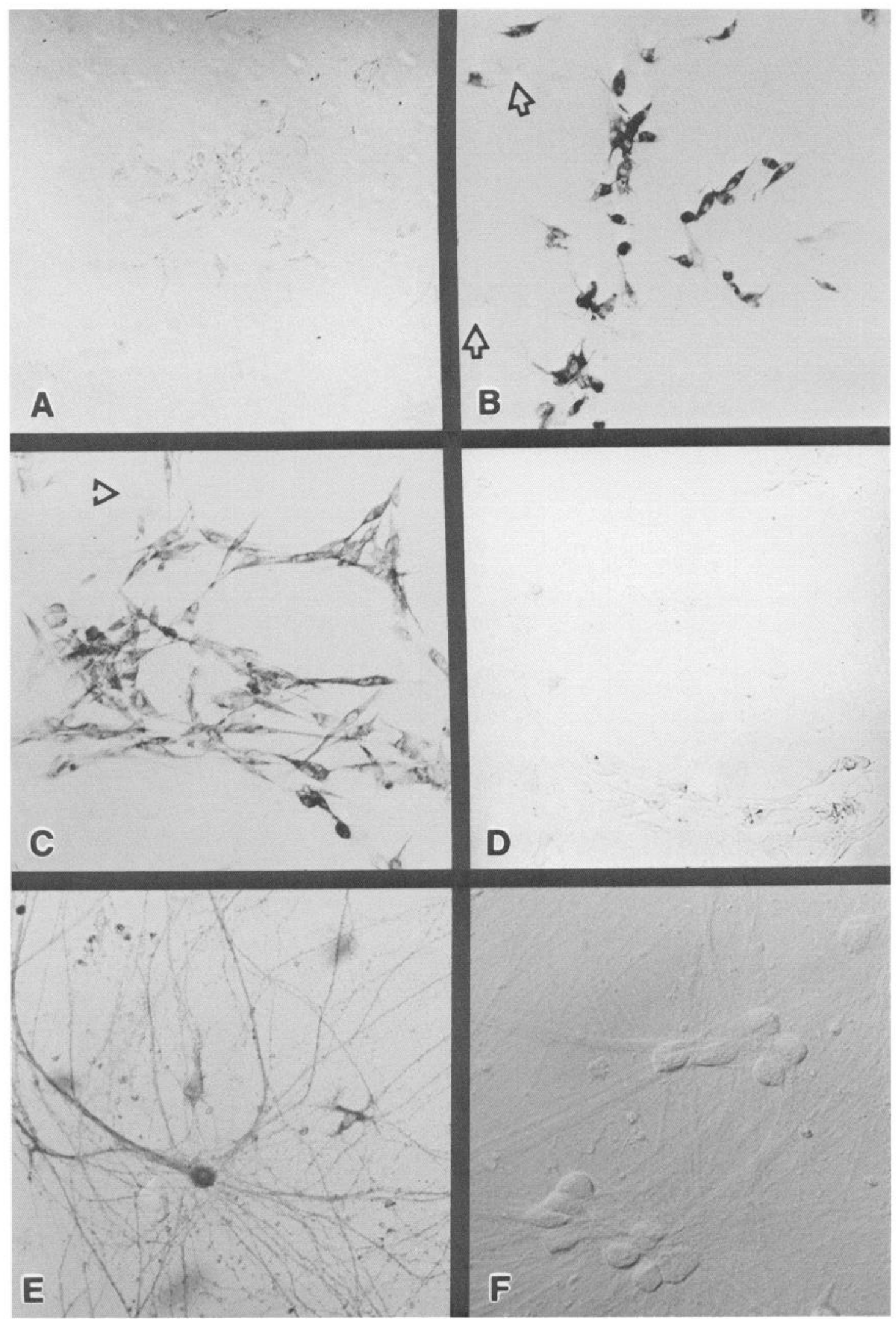

Figure 1. Immunohistochemical localization of NGF receptors on cultured rat Schwann cells. Cultures were stained with 192-IgG or mouse myeloma protein as described in Materials and Methods. $A, 192-\mathrm{IgG}$ staining on cultures $1 \mathrm{~d}$ after plating on $0.1 \%$ polylysine-covered glass slide chambers. $B, 192-\mathrm{IgG}, \mathrm{d} 3 . C, 192-\mathrm{IgG}, 7 \mathrm{~d}$ cultures. $D$, Mouse myeloma protein staining of $7 \mathrm{~d}$ cultures. $E$, 192 -IgG staining of 7 -d-old rat SCG cultures. $F$, Staining of SCG cultures with mouse myeloma protein. The reaction of the glucose oxidase marker enzyme with substrate produced a blue/purple color. Note the increased staining intensity of 192-IgG from day 1 to day 7 cultures and the failure of fibroblasts (arrow) to stain. $\times 200$. 


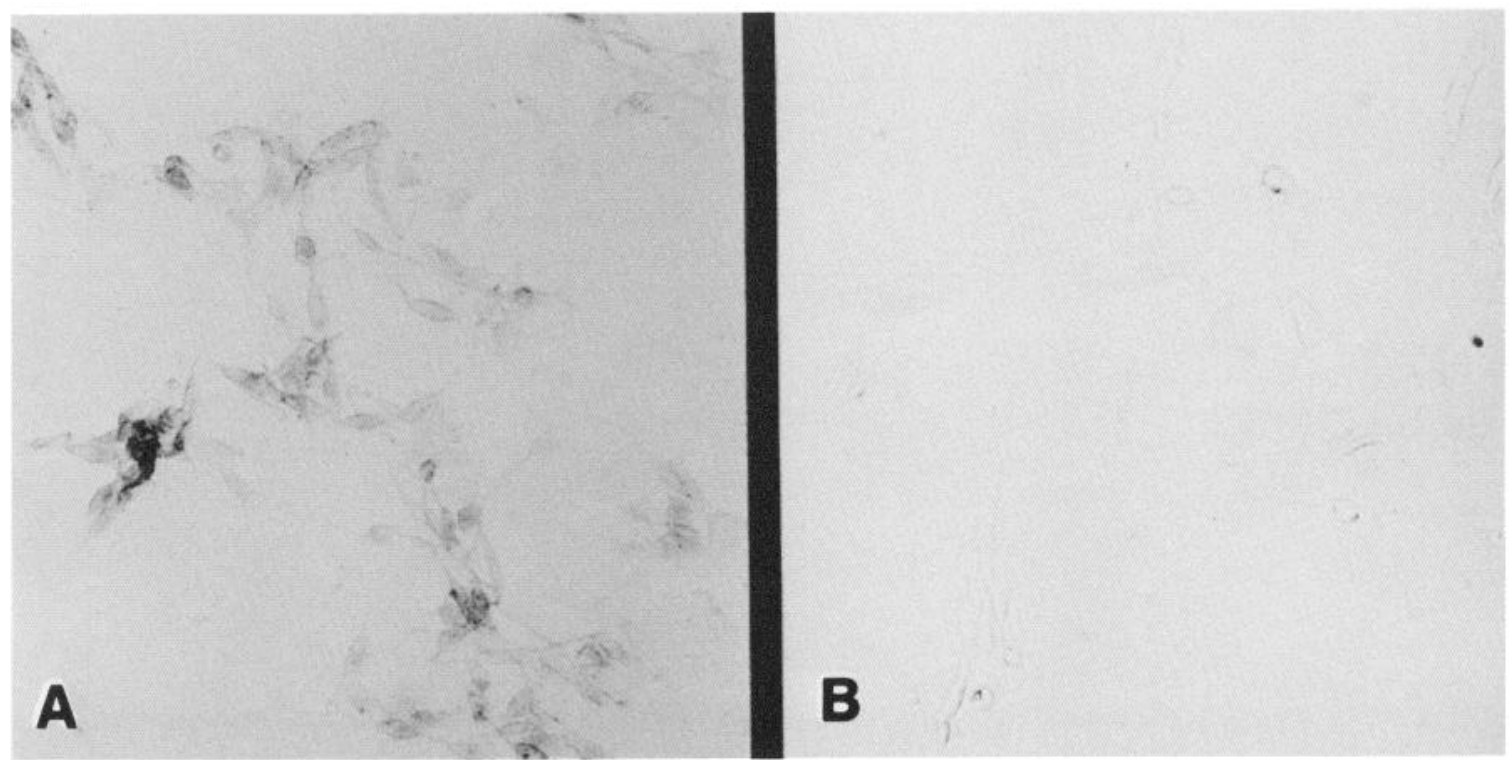

Figure 2. S-100 staining of rat Schwann cell cultures. Cells were fixed in $100 \%$ ethanol to allow permeabilization of cells and access of antibody to antigen. The pattern of S-100 staining $(A)$ is similar to that seen with 192-IgG in 7-d-old cultures (Fig. 1C). Normal rabbit serum produced no positive staining $(B) . \times 200$.

cells, and not the small population of contaminating fibroblasts, we used 192-IgG to localize immunohistochemically NGF receptors. The intensity of staining with $192-\mathrm{IgG}$ increased with time in culture (Fig. 1, $A-C$ ). Staining with 192-IgG was faint on 1-d-old cultures and increased in intensity at 3 and $7 \mathrm{~d}$ in culture. Note that in all cultures the staining was confined to the spindle-bipolar-shaped cells. Cells with fibroblast-like morphologies were present in low numbers in these cultures, and they did not stain positively with $192-\mathrm{IgG}$. Sister cultures incubated with mouse myeloma protein as a negative control (Fig. $1 D)$ showed no positive staining on the Schwann cell cultures.

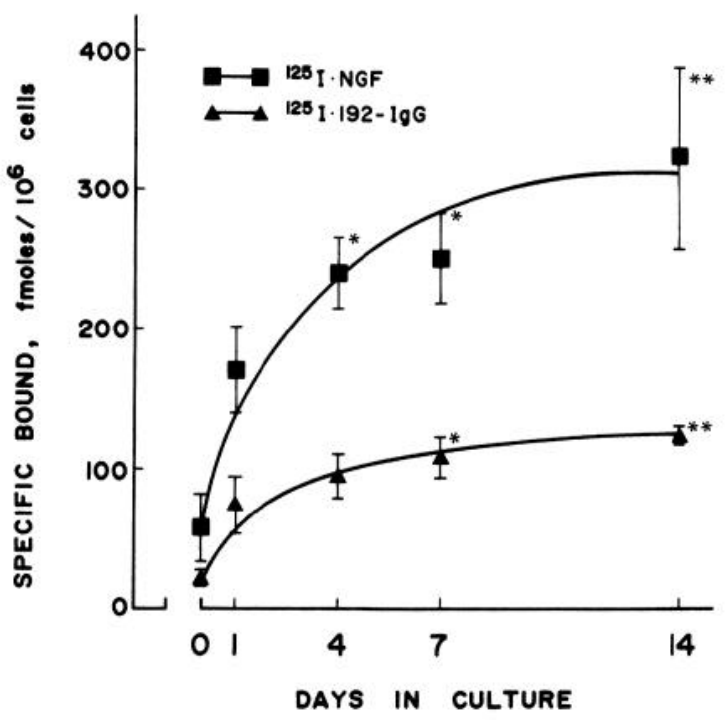

Figure 3. Time course of ${ }^{125} \mathrm{I}-\mathrm{NGF}$ and ${ }^{125} \mathrm{I}-192-\mathrm{IgG}$ binding to cultured Schwann cells. Cells were harvested after various times in culture and resuspended at concentrations ranging from 1.0 to $5.0 \times 10^{6}$ cells/ $\mathrm{ml}$. Binding was performed with each ligand $(20 \mathrm{nM})$ on ice for $80 \mathrm{~min}$ (NGF) or $1 \mathrm{hr}(192-\mathrm{IgG})$. Points represent the means \pm SD from at least 3 separate experiments. ${ }^{*} p<0.05,{ }^{* *} p<0.01$, compared to day 0, ANOVA, Dunnett's test.
As a positive control for NGF receptor staining, SCG neurons grown in culture were stained with $192-\mathrm{IgG}$ or the mouse myeloma protein. Both the cell bodies and the extensive neurite network of SCG neurons grown in tissue culture stained intensely for NGF receptor (Fig. $1 E$ ), while sister cultures incubated with the mouse myeloma protein showed no staining (Fig. $1 F$ ). In addition, no staining occurred following incubation with a variety of nonsense monoclonal antibodies (not shown).

To confirm that the bipolar, spindle-shaped cells were indeed Schwann cells, cultures were stained for the S-100 protein, a known marker for peripheral and central glia (Moore, 1965). Figure $2 A$ shows that the Schwann cells stained positively for the $\mathrm{S}-100$ protein with a similar distribution of staining as with 192-IgG. Again, fibroblast-like cells with distinct morphological features did not stain for the $\mathrm{S}-100$ protein. Also, no positive staining was evident on these cultures following incubation with normal rabbit serum (Fig. $2 B$ ). Taken together these data show that cells which bear NGF receptors in these cultures are the same as those which stain for the classical Schwann cell marker, the $\mathrm{S}-100$ protein.

\section{Time course of appearance of NGF receptors on cultured Schwann cells}

Figure 1, $A-C$, shows a marked change in the intensity of NGF receptor staining, indicating that NGF receptor number increases on these cells with time in culture. To quantitate this, Schwann cells were cultured for $0-14 \mathrm{~d}$, and ${ }^{125}$ I-NGF or ${ }^{125} \mathrm{I}-$ 192-IgG binding was assayed on the harvested cells by using 20 nM of iodinated ligand. Cells that were freshly dissected from P1 rats (day 0) had very low NGF and 192-IgG binding levels; however, binding of both ligands increased significantly after 1-14 $\mathrm{d}$ in culture (Fig. 3). In some experiments, binding was determined on 21 - and 27-d-old cultures, and binding remained elevated (data not shown). To test whether the low level of binding at day 0 was due to enzymatic treatment of the dissected nerves, 4-d-old Schwann cell cultures were harvested and sub- 


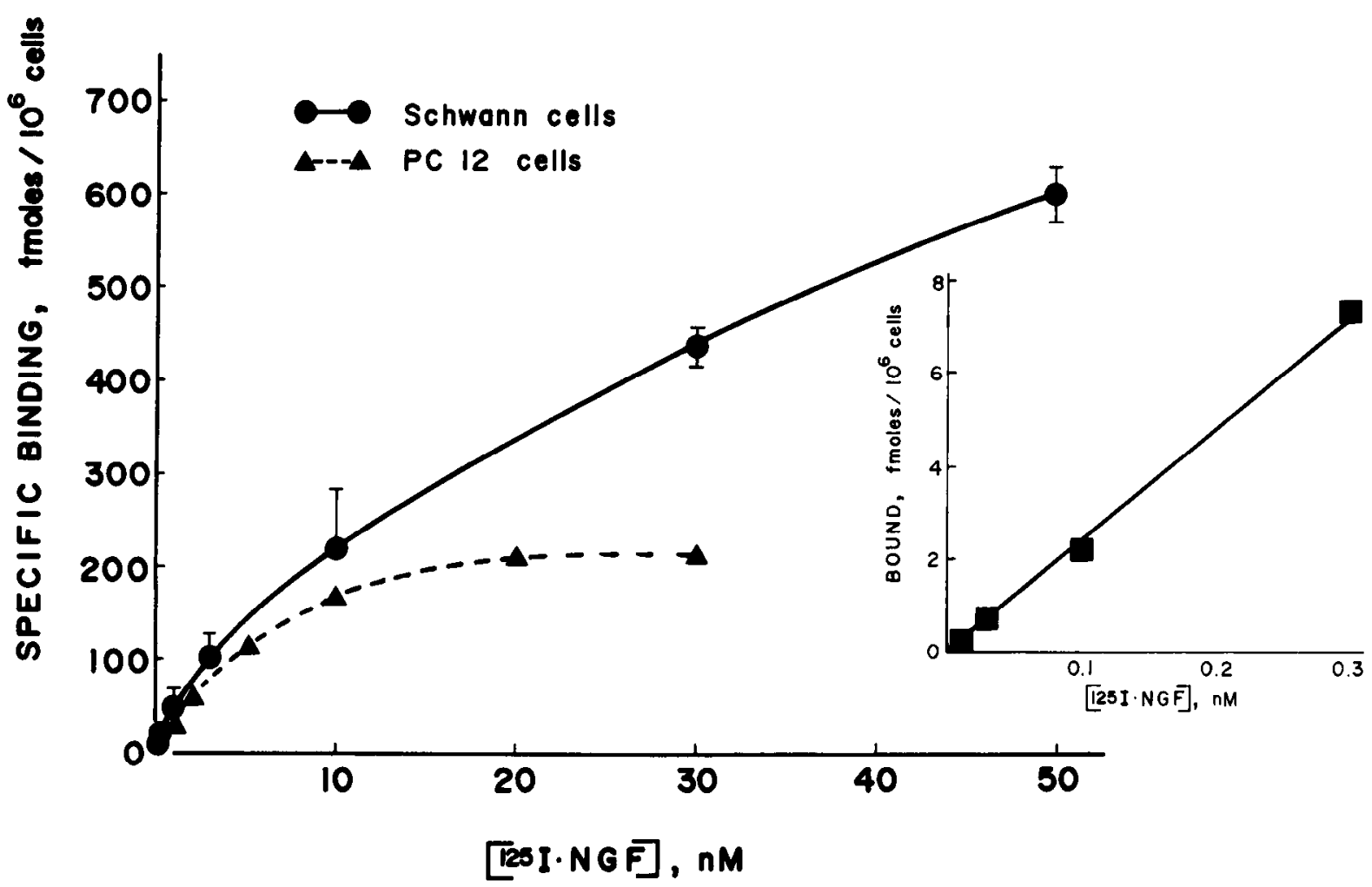

Figure 4. Binding isotherm of ${ }^{125}$ I-NGF to cultured Schwann cells and PC12 cells. Schwann cells for these experiments were grown for $4 \mathrm{~d}$ as described in Materials and Methods. Cells were resuspended in binding buffer at 2-3 $\times 10^{6}$ cells $/ \mathrm{ml}$. ${ }^{125} \mathrm{I}-\mathrm{NGF}$ concentrations of $0.3-5.0 \mathrm{nM}$ were used for initial experiments on Schwann cells (circles) and PC12 cells (triangles). Insert, Binding of $0.01-0.30$ nM ${ }^{125}$ I-NGF to cultured Schwann cells (squares). Specific binding was expressed as fmoles ${ }^{125}\left[-N G F\right.$ bound $/ 10^{6}$ cells. Values with error bars represent means \pm SD of at least 3 independent experiments. Other values are reprentative of 1 experiment performed in triplicate.

jected to collagenase treatment for $1 \mathrm{hr}$ to reproduce the conditions used in the isolation of the cells. The binding of labeled NGF or 192-IgG was then measured. Enzymatic treatment resulted in a loss of approximately $50 \%$ of the NGF or $192-\mathrm{IgG}$ binding sites compared to non-enzyme-treated cells. If the value of ligand binding at day 0 is doubled, there is still a significant increase in receptor levels with time in culture. It has been shown in vivo that the NGF receptor content in the distal portion of a cut nerve increases with time after lesion (Taniuchi et al., 1986b), indicating that loss of neuronal contact to Schwann cells results in increased NGF receptor number. The data shown in Figure 3 support this and provide a reliable in vitro model of NGF receptor induction in Schwann cells. As would be expected, the time courses of increased NGF and 192-IgG binding were identical; however, since both ligands were used at a concentration that yields maximal binding in neurons or PCl 2 cells, the striking difference in the amounts of specific binding were unexpected and suggested some difference in the binding of these ligands to Schwann cells compared to PC12 cells, where both ligands label the same number of sites (Chandler et al., 1984).

\section{Characterization of ${ }^{125} I-N G F$ and ${ }^{125} I-192-I g G$ binding to Schwann cells}

To determine the $K_{\mathrm{d}}$ and $B_{\text {max }}$ values for ${ }^{125}$ I-NGF and ${ }^{125}$ I-192IgG binding to Schwann cells, 4 -d-old cultures were prepared and the cells were incubated with varying concentrations of labeled ligands. Normally, NGF binds to cell-surface receptors in a saturable manner and, in neurons and PC12 cells, binds to
2 kinetically distinct binding sites. The binding of ${ }^{125}$ I-NGF to cultured Schwann cells (Fig. 4) showed an unusual profile in that saturation of binding was not fully achieved at $50 \mathrm{~nm}{ }^{125} \mathrm{I}-$ NGF. In other experiments, similar results were obtained with binding still increasing at NGF concentrations of $70 \mathrm{nM}$ (data not shown). In contrast, $\mathrm{PCl} 2$ cells, assayed under identical conditions with the same preparations of ${ }^{125} \mathrm{I}-\mathrm{NGF}$, exhibited a normal adsorption isotherm when assayed at $0.5-30 \mathrm{nM}$; max-

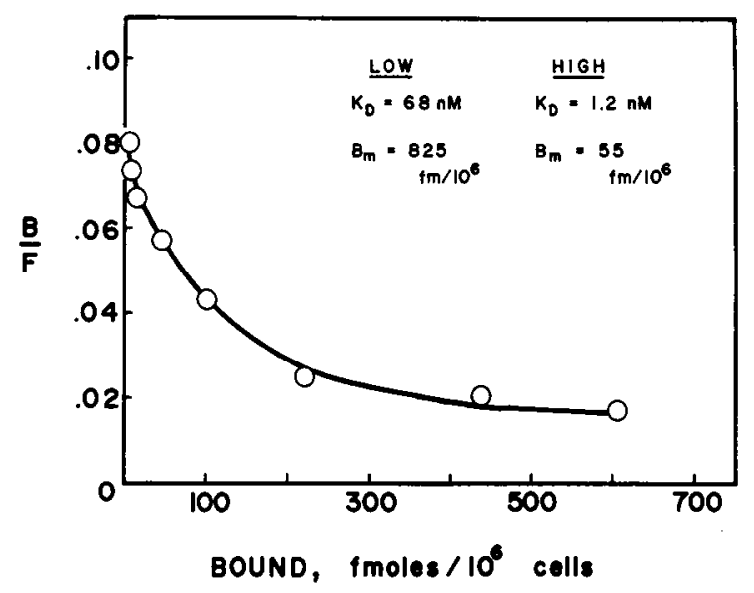

Figure 5. Scatchard plot $(B / F$ vs $B)$ of ${ }^{125}$ I-NGF binding data of Figure 4. The nonlinear transformation was fitted to a 2-line plot by the method of Feldman (1972). $K_{\mathrm{d}}$ and $B_{\max }$ values for high- and low-affinity NGF binding sites were estimated (see text). 
Figure 6. Specific ${ }^{125}$ I-192-IgG binding to rat Schwann cells. Four-day-old cultures were used for these experiments and resuspended at a concentration of $3 \times 10^{6}$ cells $/ \mathrm{ml}$. Ligand concentrations of $0.5-30 \mathrm{nM}$ were employed, and binding was carried out for $1 \mathrm{hr}$ on ice. Binding was expressed as fmoles ${ }^{125} \mathrm{I}-192-\mathrm{IgG}$ bound $/ 10^{6}$ cells. The binding transformed to a linear Scatchard plot (insert), and intercepts were determined by linear-regression analysis. Points represent the means \pm $\mathrm{SD}$ of 3 separate experiments.

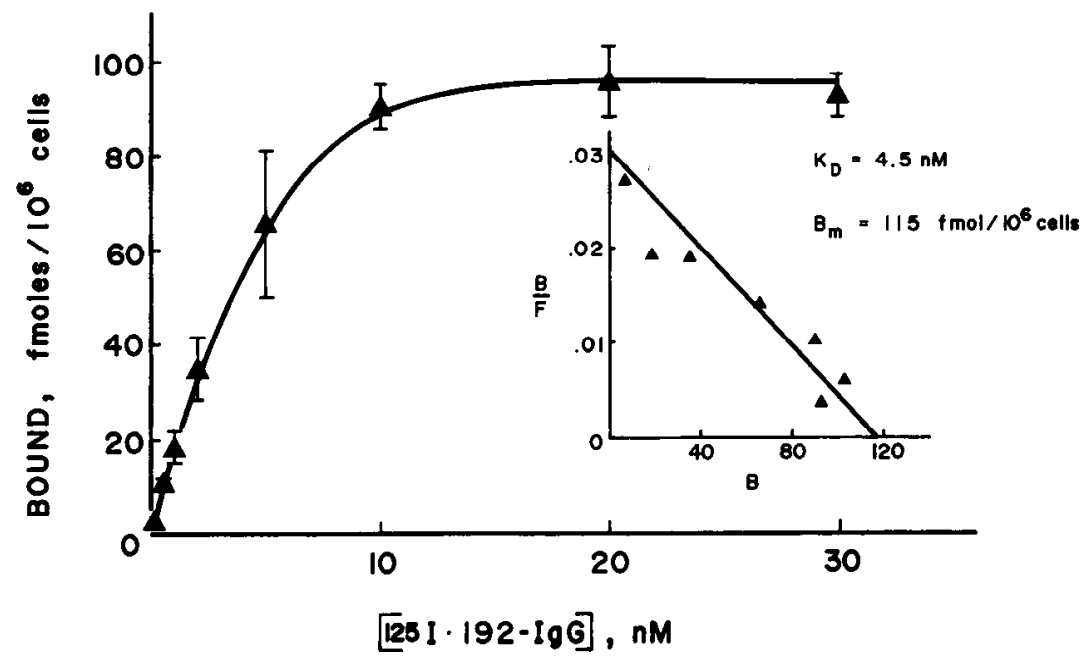

imal binding occurred at approximately $20 \mathrm{nM}$. To ascertain whether a saturable binding component existed on Schwann cells at low concentrations of NGF, Schwann cells were incubated with $0.01-0.30 \mathrm{nM}^{125}$ I-NGF. The insert of Figure 4 shows that no apparent plateau was detected, as binding was essentially linear from $10 \mathrm{pm}$ to $1 \mathrm{~nm}$ of ligand. Thus, no saturable component was observed in the concentration range of the highaffinity receptor associated with sympathetic and sensory neurons and with $\mathrm{PC} 12$ cells. Scatchard transformation of the NGF binding data from Schwann cells yielded a curvilinear plot (Fig. 5). To gain an approximation of $K_{\mathrm{d}}$ and $B_{\max }$ values, the data were subjected to a computerized program that fitted 2 distinct lines to the data points (Feldman, 1972). Using this method of estimation, the higher-affinity binding site had a $K_{\mathrm{d}}$ of $1.2 \mathrm{nM}$ and a calculated $B_{\max }$ value of $55 \mathrm{fmol} / 10^{6}$ cells, while the loweraffinity site yielded $K_{\mathrm{d}}$ and $B_{\max }$ values of $68 \mathrm{nM}$ and $825 \mathrm{fmol} /$ $10^{6}$ cells, respectively. In contrast, the Scatchard plot for NGF binding on PC12 cells measured at concentrations that label the low-affinity site $(0.5-30 \mathrm{~nm})$ yielded a straight line. The apparent $K_{\mathrm{d}}$ value of $4 \mathrm{~nm}$ and the $B_{\max }$ value of $283 \mathrm{fmol} / 10^{6}$ cells agree well with those previously reported for PC12 cells. Thus it appears that the NGF binding profile to Schwann cells is distinct when compared to the binding on neurons or neuron-like cells.

The binding of the monoclonal antibody $192-\mathrm{IgG}$ to cultured Schwann cells showed a much different pattern than that for NGF (Fig. 6). Unlike NGF, 192-IgG binding was saturable at approximately $20 \mathrm{nM}$. The Scatchard plot was linear with $K_{\mathrm{d}}$ and $B_{\max }$ values of $4 \mathrm{nM}$ and $115 \mathrm{fmol} / 10^{6}$ cells, respectively. As seen from these data, the number of binding sites labeled by 192-IgG on Schwann cells was significantly fewer than those labeled by NGF when high ligand concentrations were used. However, the estimated $B_{\max }$ of NGF binding to the higheraffinity site $\left(55 \mathrm{fmol} / 10^{6}\right.$ cells $)$ is reasonably close to the observed $B_{\max }$ for $192-\mathrm{IgG}$ binding to Schwann cells ( $115 \mathrm{fmol} / 10^{\circ}$ cells),
Figure 7. Association-dissociation kinetics of $40 \mathrm{pm}{ }^{125}$ I-NGF binding to Schwann cells $(A)$ and $\mathrm{PC} 12$ cells $(B)$. Four-day-old rat Schwann cell cultures and $\mathrm{PCl} 2$ cells were used in these experiments. Cells were incubated at $37^{\circ} \mathrm{C}$ as described in Materials and Methods. Binding is expressed as a percentage of maximal binding, which occurred at 10 $30 \mathrm{~min}$ of ligand association. Cells were resuspended at concentrations of 12$15 \times 10^{6} \mathrm{cells} / \mathrm{ml}$. Values are single experiments which are representative of 3 different experiments. $O$, data points during association; $\triangle$, data points during dissociation
40 PM 125I.NGF

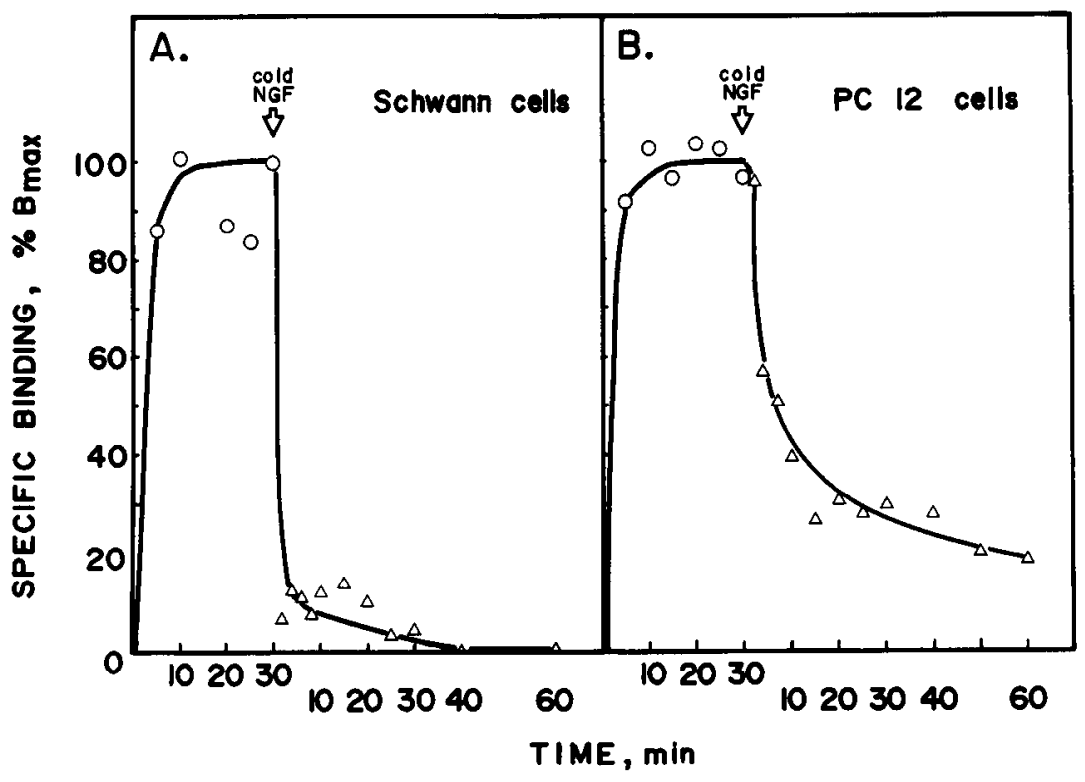




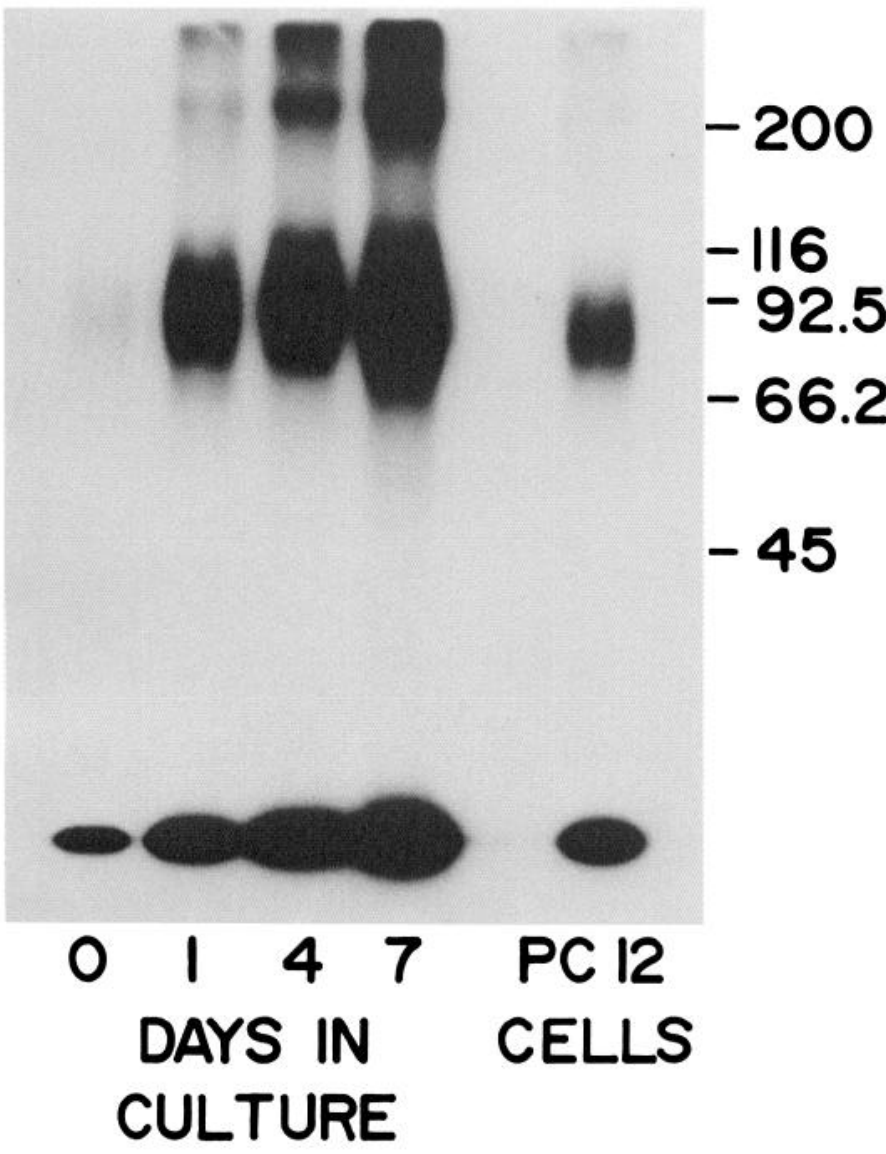

Figure 8. Autoradiogram of the time course of NGF receptor induction in cultured rat Schwann cells following SDS-PAGE. Cells were cultured for various times, and NGF receptor was assayed by using the crosslink/ immunoprecipitation assay. Samples were chromatographed on an SDS $7 \%$ polyacrylamide gel and the gels exposed to radiographic film. PC12 cells were assayed in parallel for comparison. Each lane represents the signal from 30,000 cells. Exposure time, $44 \mathrm{hr}$. Molecular-weight standards (in $\mathrm{kDa}$ ) are given to the right.

suggesting that NGF and $192-\mathrm{IgG}$ recognize the same number of a particular class of binding sites on Schwann cells with a comparable affinity (1-4 nM).

Dissociation kinetics of ${ }^{125} \mathrm{I}-\mathrm{NGF}$ binding to Schwann cells: Is there evidence for slow dissociation or internalization of NGF?

No detectable saturation of NGF binding was evident at ligand concentrations of $0.01-0.3 \mathrm{nM}$ (Fig. 4, insert). This indicated a lack of the type I or high-affinity sites that are associated with NGF internalization in NGF-dependent neurons and in PC12 cells. To determine directly whether Schwann cells display slow dissociation of NGF binding or if ligand internalization occurs, fixed concentrations of ${ }^{125} \mathrm{I}-\mathrm{NGF}$ were incubated with Schwann cells at $37^{\circ} \mathrm{C}$ for $30 \mathrm{~min}$. At this point, an excess of unlabeled NGF was added, and the dissociation of label was monitored with time. This experiment was biased in favor of conditions where internalization of ligand was likely to occur $\left(37^{\circ} \mathrm{C}\right)$. Figure $7 A$ shows that 40 pM ${ }^{125}$ I-NGF rapidly associated to Schwann cells at $37^{\circ} \mathrm{C}$. After the addition of unlabeled NGF, virtually all of the binding dissociated within $2 \mathrm{~min}$. To compare this to a cell type that is known to bear high-affinity NGF receptors and to internalize NGF bound to its cell-surface receptor, the identical experiment was performed on PC12 cells. Figure $7 B$ shows

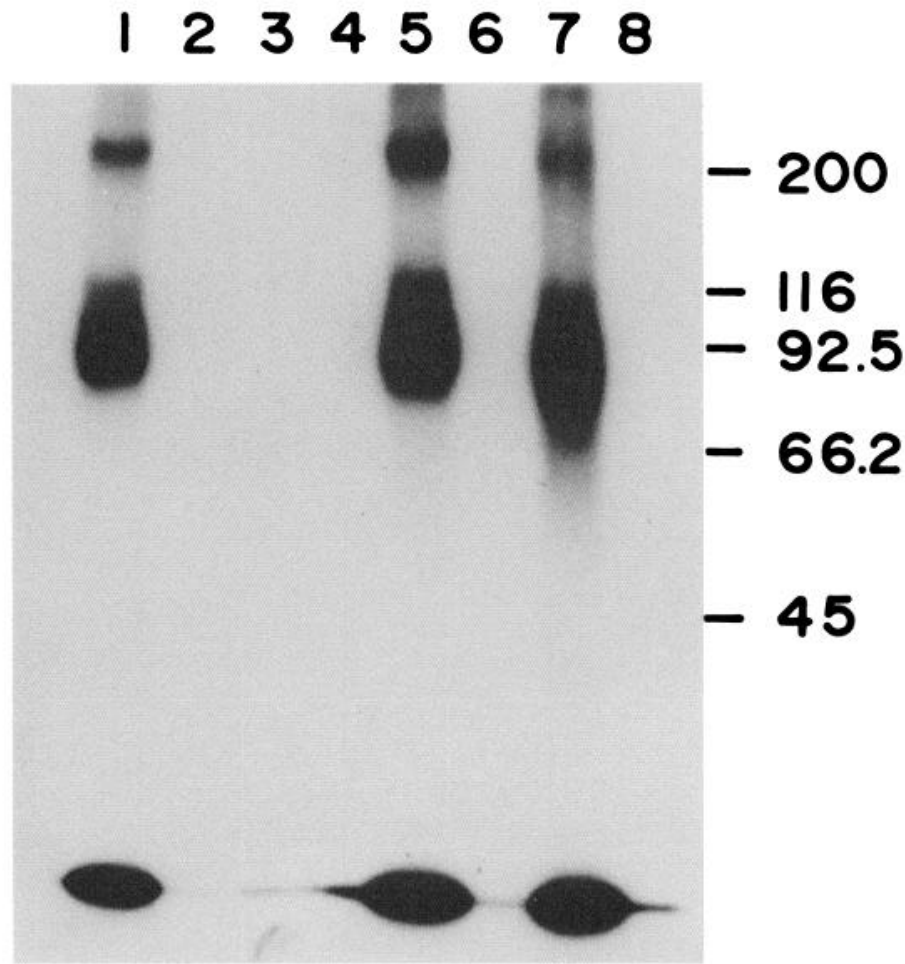

Figure 9. Characterization of immunoprecipitated NGF receptor from sciatic nerve- and vagus nerve-derived Schwann cells. The NGF receptor species were visualized as described in Figure 9. Lane 1, ${ }^{125}$ I-NGF crosslinked receptor from sciatic nerve-derived Schwann cells immunoprecipitated with $10 \mu \mathrm{g} \mathrm{192-IgG;} \mathrm{lane} \mathrm{2,} \mathrm{signal} \mathrm{obtained} \mathrm{when} \mathrm{300-}$ fold excess of NGF was added to initial binding reaction; lane 3, ${ }^{125} \mathrm{I}-$ NGF crosslinked receptor immunoprecipitated with $10 \mu \mathrm{g}$ mouse myeloma protein; lane 4, crosslinked receptor immunoprecipitated with monoclonal antibody 187; lanes 5 and 6 , same as lanes 1 and 2 using vagus nerve-derived Schwann cells; lanes 7 and 8 , same as in lanes 1 and 2 using PC12 cells. Each lane represents 60,000 cells. Exposure time, $20 \mathrm{hr}$. Molecular-weight standards at right.

that approximately $20-30 \%$ of the NGF bound to PC12 cells, under these conditions, was not dissociable $1 \mathrm{hr}$ after the addition of unlabeled NGF. Similar experiments were carried out with $0.3-30 \mathrm{nM}^{125} \mathrm{I}-\mathrm{NGF}$ under a variety of temperatures. Under no conditions was there any evidence for slow dissociation or internalization of NGF in the Schwann cells, whereas the PC12 cells routinely demonstrated a slow-dissociating (or internalized, this paradigm does not distinguish between the two) component of bound NGF. Finally, similar experiments showed that $192-\mathrm{IgG}$ (3 $\mathrm{nm}$ ) binding was also completely dissociable from Schwann cells (data not shown).

\section{Immunoprecipitation and visualization of $N G F$ receptor on Schwann cells}

The monoclonal antibody 192-IgG has been shown to be a useful tool to immunoprecipitate the rat NGF receptor from various tissues and cell preparations and to determine molecular weights of the NGF receptor proteins. To determine whether the NGF receptor localized to Schwann cells was similar to or different from that of the PC12 cell line, we performed the NGF crosslink-immunoprecipitation assay on these cells as described in Materials and Methods. In PC12 cells, as well as in various NGF-dependent neurons, the 192-IgG immunoprecipitated NGF-NGF receptor complex appears as 2 distinct bands on an SDS-polyacrylamide gel with molecular weights of 90 and 210 
Figure 10. A, Quantitation of NGF receptor levels in freshly isolated Schwann cells from E19, E20, P1, and $\mathrm{P} 3$ rats. Cells were isolated and incubated with $10 \mathrm{~nm}{ }^{125}$ I-NGF, as described in Materials and Methods. NGF receptor was quantitated by using the crosslink/immunoprecipitation assay. E20, P1, and P3 Schwann cells after 4 and $7 \mathrm{~d}$ in culture. Schwann cells isolated from rats at different ages were placed in culture and monitored for NGF receptor content, 4 and $7 \mathrm{~d}$ after plating, by using the crosslink/immunoprecipitation assay. Values are from a single experiment performed in triplicate and presented as fmoles ${ }^{125}$ I-NGF crosslinked $/ 10^{6}$ cells. Numbers are corrected for nonspecific binding, which never exceeded $8 \%$ in this experiment. $B$, Increase in NGF receptor levels of

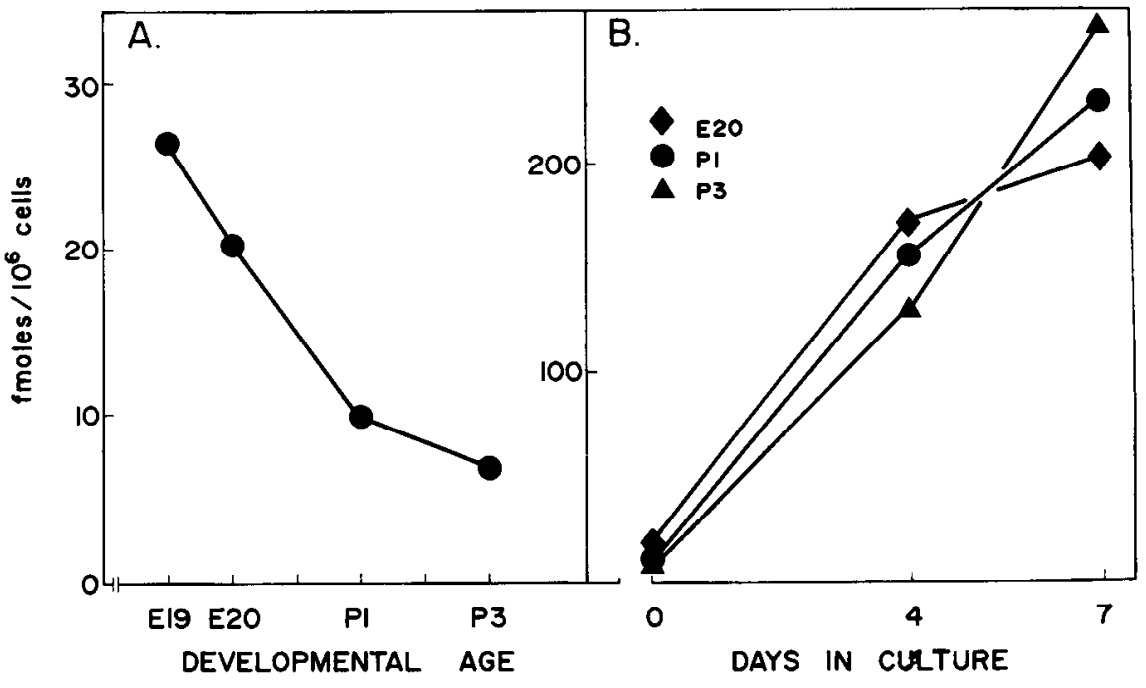

$\mathrm{kDa}$. In the present experiments the immunoprecipitated NGFNGF receptor complex from Schwann cells migrated slightly slower on SDS gels compared to PC1 2 cells (Figs. 8, 9), yielding 2 variants with apparent molecular weights of 95 and $220 \mathrm{kDa}$. Figure 8 shows that the molecular weights of these 2 bands did not change with time in culture; however, there appeared to be an increased relative amount of the higher-molecular-weight $(220 \mathrm{kDa})$ species with time in culture. Also, the $220 \mathrm{kDa}$ species is much more prevalent in 4- and 7-d-old Schwann cell cultures than the higher-molecular-weight species of the NGF receptor on PC12 cells. To demonstrate the specificity of the crosslink/ immunoprecipitation procedure in Schwann cells, an excess of NGF in the binding step prevented the appearance of the 2 receptor species on the gel (Fig. 9, lanes 1 and 2). Similarly, if the receptor was immunoprecipitated with the mouse myeloma protein (lane 3) or monoclonal antibody 187 (lane 4), there was no appearance of receptor. Other nonsense monoclonal antibodies were tested in this manner, and no specific immunopre-

Table 1. Quantitation of ${ }^{125}$ I-NGF crosslinked receptor from Schwann cells, astrocytes, and PC12 cells immunoprecipitated with 192-IgG and other antibodies

\begin{tabular}{llll} 
Cell type & $\begin{array}{l}\text { Cold } \\
\mathrm{NGF}^{a}\end{array}$ & $\begin{array}{l}\text { Precipitating } \\
\text { antibody }^{b}\end{array}$ & $\begin{array}{l}\text { fmol/ } \\
10^{6} \text { cells }\end{array}$ \\
\hline Sciatic nerve Schwann cells & - & $192-\mathrm{IgG}$ & $33.6^{c}$ \\
& + & $192-\mathrm{IgG}$ & $\mathrm{ND}^{d}$ \\
& - & $\mathrm{MMP}^{c}$ & $\mathrm{ND}$ \\
& - & 187 & $\mathrm{ND}$ \\
Vagus nerve Schwann cells & - & $192-\mathrm{IgG}$ & 94.7 \\
& + & $192-\mathrm{IgG}$ & $\mathrm{ND}$ \\
Astrocytes & - & $192-\mathrm{IgG}$ & $\mathrm{ND}$ \\
& + & $192-\mathrm{IgG}$ & $\mathrm{ND}$ \\
PC12 cells & - & $192-\mathrm{IgG}$ & 18.3 \\
& + & $192-\mathrm{IgG}$ & $\mathrm{ND}$
\end{tabular}

a 300 -fold excess of unlabeled NGF added in the initial binding reaction.

${ }^{b}$ Monoclonal antibody used to immunoprecipitate the NGF-NGF receptor complex.

${ }^{r}$ Cells were incubated with $2 \mathrm{nM}^{125} \mathrm{I}-\mathrm{NGF}$ as described in Materials and Methods. Values expressed as fmoles of ${ }^{125}$ I-NGF crosslinked per $10^{6}$ cells.

$d$ Not detectable. Level of detectability determined as twice the blank (nonspecific) value.

${ }^{r}$ MMP, mouse myeloma protein. cipitation of NGF-NGF receptor complexes occurred (data not shown).

In vivo experiments show that all Schwann cells in the lesioned distal nerve appear to express NGF receptors (Taniuchi et al., 1986b). This suggests that Schwann cells ensheathing NGF nonresponsive motor axons, as well as sympathetic and sensory axons, in the sciatic nerve increase their NGF receptor levels. To test for the presence of NGF receptors on Schwann cells which normally do not ensheath axons of NGF-dependent neurons, we cultured Schwann cells from the vagus nerve of $P 1$ rats and assayed these cells for NGF receptor content (Fig. 9, lanes 5 and 6). While the NGF receptors localized to vagus nerve Schwann cells comigrated with those derived from the sciatic nerve, there were approximately 2-3 times as many receptors on the vagus nerve Schwann cells compared to sciatic nerve Schwann cells. A similar result was obtained by using the wholecell ligand binding assay with ${ }^{125}$ I-NGF as the receptor probe (data not shown).

Finally, astrocytes cultured from neonatal rat cerebral cortex were assayed for NGF receptor by using the sensitive immunoprecipitation assay. Unlike their peripheral nervous system counterparts, the astrocytes from P6 rats maintained in culture for 6-8 $\mathrm{d}$ had no detectable levels of NGF receptor. The quantitative assessment of NGF receptors on Schwann cells, astrocytes, and PC1 2 cells using the crosslink-immunoprecipitation assay is given in Table 1 .

\section{Developmental aspects of the Schwann cell NGF receptor}

In a recent report by Yan and Johnson (1987) it was demonstrated that the NGF receptor content in sciatic nerve decreased dramatically from embryonic day 20 to adulthood in rats. As one possible explanation for this decrease, it was proposed that Schwann cells within the nerve expressed high levels of NGF receptor during development and that NGF receptors on Schwann cells decreased as the axon/Schwann cell interaction matured. During the course of the present studies it was noticed that the NGF receptor content of E20 Schwann cells immediately after isolation was significantly higher than that of P1 Schwann cells. Likewise, P3 cells had lower NGF receptor levels than P1 cells. To see whether NGF receptors were developmentally regulated in these cells, Schwann cells were prepared from E19, E20, P1, and P3 rats and assayed immediately for NGF receptor content using the crosslink-immunoprecipitation 
assay. In addition, Schwann cells from rats of various ages were cultured for 4 and $7 \mathrm{~d}$ to observe the relative fluctuations in receptor density as a function of time in culture. Figure $10 \mathrm{~A}$ shows an age-dependent decline in Schwann cell NGF receptor content from E20 to P3, determined immediately after dissociation. If the cells were allowed to grow in culture for 4 and 7 $\mathrm{d}$, the NGF receptor number increased dramatically, as previously observed, regardless of the age of the cells when plated (Fig. 1OB). These data suggest that developing Schwann cells bear NGF receptors in vivo and that developing Schwann cells at all ages examined have a similar capacity to induce NGF receptors in response to loss of axonal contact.

\section{Discussion}

The results of the present study showed that rat Schwann cells, grown in tissue culture, express NGF receptors or binding sites on their cell surface and that the binding of NGF to these cells increases with time in culture. By using ligand binding and autoradiographic techniques, Sutter et al. (1979a) and Carbonetto and Stach (1982) have demonstrated specific NGF binding sites on morphologically distinct non-neuronal cells in chicken sensory neuronal cultures and estimated a binding constant of approximately $2 \times 10^{-9} \mathrm{M}$ for NGF on these cells. It was subsequently shown that NGF receptors in non-neuronal cells in chick sympathetic or sensory neuronal cultures appear developmentally regulated. Binding sites are observed after $24 \mathrm{hr}$ in culture when removed on E6 (Zimmermann and Sutter, 1983), whereas levels are much lower in 24-hr cultures obtained from E12 to E16 chick embryos (Rohrer, 1985). In the rat, we have shown that freshly prepared (day 0) Schwann cells from E19P3 rats have NGF binding sites. By using the monoclonal antibody 192-IgG (Chandler et al., 1984) as an immunohistochemical tool, we verified that the Schwann cells (S-100 positive) in these cultures, and not the small population of fibroblast-like cells, possess NGF receptors. These results, coupled with the results obtained in vivo (Taniuchi et al., 1986b) indicate that the presence of NGF receptor detected by $192-\operatorname{lgG}$ may serve as a means of marking Schwann cells devoid of axonal contact.

In vivo NGF receptor content in distal crushed sciatic nerve increases with time after crush (Taniuchi et al., 1986b). Receptor levels are low but detectable at days 1 and 3 . By 7-14 d, the receptor content increases 20- to 50-fold. A similar time course of NGF and 192-IgG binding was seen with Schwann cells placed in culture (see Fig. 3). Thus, the tissue culture model described here closely parallels the in vivo results with respect to NGF receptor induction after axotomy and provides a good model to study NGF receptor regulatory processes when Schwann cells lose their functional contact with neuronal elements. Although the increase in NGF binding in cultured cells did not approach the magnitude of that seen for adult rats in vivo, it represented a substantial increment in binding. The probable explanation for the less dramatic increase is that Schwann cell NGF receptor number may be much higher in prenatal and early neonatal animals and decline substantially as the nerve develops to maturity in the adult. This implics a rolc for the Schwann cell NGF receptor in development as well as in regenerative processes (see below). In support of this, Figure 10 shows that NGF receptor binding on freshly prepared E19 Schwann cells is 3-4 times higher than on P3 Schwann cells. Extrapolation of this developmental curve to adulthood would yield the observed lower binding levels (Yan and Johnson, 1987). Thus, adult Schwann cells have very few or no NGF receptors, resulting in the greater differences in response to nerve injury (loss of neuronal contact).

\section{Ligand binding and dissociation studies}

Conventionally, NGF binding to cell-surface NGF receptors is saturable and often transforms to a curvilinear Scatchard plot. With chicken sensory neurons (Sutter et al., 1979b), chick sympathetic neurons (Frazier et al., 1974; Olender and Stach, 1980), and PC12 cells (Buxser et al., 1983), NGF exhibits binding to 2 classes of receptors. The high-affinity receptors, termed type I, bind NGF with a $K_{\mathrm{d}}$ of $10^{-11}-10^{-10} \mathrm{M}$. The $K_{\mathrm{d}}$ for the loweraffinity or type II receptors is in the $10^{-9} \mathrm{M}$ range. Figure 4 shows that NGF binding does not saturate on Schwann cells grown in culture for $4 \mathrm{~d}$. In contrast, the identical reagents assayed on PC12 cells, under conditions designed to label the low-affinity receptor $\left(10^{-9} \mathrm{M}\right)$ showed a distinct saturation binding isotherm with $K_{\mathrm{d}}$ and $B_{\max }$ values that agree quite well with those reported previously (e.g., Herrup and Thoenen, 1979; Chandler et al., 1984). Two possible explanations can be offered to account for the aberrant binding kinetics of NGF to Schwann cells. First, NGF binding to Schwann cells may show negative cooperative behavior such that saturation is not achieved at the concentrations used in these experiments (50-70 nM). There is no evidence in favor of a cooperative effect of NGF binding (Suttcr et al., 1979b). A second alternative is that NGF binds to one or more cell-surface molecules that are distinct from the Schwann cell NGF receptor, show a weak attraction for NGF, and have the capacity to bind large amounts of NGF.

In contrast to NGF binding, the binding of the anti-receptor monoclonal antibody, 192-IgG, was saturable and transformed to a linear Scatchard plot (Fig. 6). The affinity constant of $4 \mathrm{~nm}$ obtained for 192-IgG on Schwann cells is similar to that observed for rat sympathetic ganglion membranes (Taniuchi and Johnson, 1985) and PCl 2 cells (Chandler et al., 1984). 192-IgG labels the same number of binding sites as NGF in PC12 cells (Chandler et al., 1984), a result we have confirmed. On Schwann cells, 192-IgG labels a significantly lower number of binding sites than does NGF (100 versus approximately 800 for NGF) but a similar number to the calculated $1.2 \mathrm{~nm} K_{\mathrm{d}}$ component of NGF binding on Schwann cells. This is consistent with the contention that NGF may bind with low affinity to cell-surface proteins other than the NGF receptor. Alternatively, the NGF receptor may be structurally different, or it may present itself on the Schwann cell surface in such a manner that the epitope recognized by $192-\mathrm{IgG}$ is not readily exposed, yielding the apparently fewer 192-IgG binding sites. The observation that the molecular weights of the NGF receptors on Schwann cells seem to differ slightly from those of PC12 cells (Fig. 8) suggests that this might be the case. It should be noted, however, that kinetic or structural properties of NGF could be affected by culture conditions. For example, Schwann cells were cultured in the presence of the antimitotic agent cytosine arabinoside. Similar experiments (unpublished observations) performed on a rat Schwannoma cell line, cultured obviously in the absence of an antimitotic, yielded the same kinetic and structural characteristics of the NGF receptor as seen on Schwann cells. These data suggest that the kinetic and structural differences observed in primary Schwann cell cultures are a reflection of the Schwann cell phenotype rather than a function of culture conditions.

\section{NGF receptors on other glial cells}

With regard to NGF receptor expression, vagus nerve-derived Schwann cells behave similarly to their sciatic nerve-derived 
counterparts when deprived of axonal contact (Fig. 9). This is interesting given the fact that the Schwann cells prepared for these experiments were dissected from a region presumably devoid of axons from NGF-dependent neurons. Thus, Schwann cells appear to respond in a generalized fashion regardless of the axons they ensheath. Similar results are obtained in vivo: Section of the vagus nerve results in increased NGF receptor levels distal to the lesion (Taniuchi et al., submitted). In vivo it appears that Schwann cells from nerves with varying fiber compositions behave similarly with regard to certain biochemical and morphological parameters during phases of development (Asbury, 1967), as well as during injury or disease (Thomas, 1948; Asbury and Arnason, 1968). In tissue culture, Schwann cells from different regions and different species proliferate in response to mitogens in a uniform manner (Pleasure et al., 1985).

In contrast to their PNS counterparts, cultured rat astrocytes contained no detectable NGF binding sites (Table 1). It has long been known that the regenerative capacity of CNS axons is blunted compared with that of peripheral axons (Guth, 1975; Veraa and Grafstein, 1981). However, if central axons are given the proper environment, they will regenerate with a greatly enhanced efficiency (David and Aguayo, 1981; Aguayo et al., 1983; sce revicw, Bjorklund and Stcncvi, 1979). Scveral factors claborated by Schwann cells have been implicated in the success of peripheral axons to regenerate. Whether these factors are present or biologically active in astrocytes and oligodendrocytes is uncertain. Recent results from this laboratory have shown that lesioning of CNS axons does not produce the increases in NGF receptor levels observed in peripheral nerve (Taniuchi et al., unpublished observations). Perhaps one aspect of the inability of the CNS to promote regeneration is that central glia do not present NGF receptors, or other neurotrophic factor receptors, on their cell surface by which to concentrate trophic factors supportive of functional regeneration (see below).

\section{Role of NGF receptors on Schwann cells}

During various stages of neuronal development and regeneration it is apparent that the cellular and extracellular components within a nerve have a critical function in the guidance of the axon to its target (see review, Sanes, 1983). Several investigators have identified one or more molecules that have important roles during development and regeneration (Müller et al., 1986). Laminin (Manthorpe et al., 1983) and the neuron-glial cell adhesion molecule (Friedlander et al., 1986) are 2 examples of such molecules. It is likely that several molecules, interacting in a complex manner, are involved in the proper guidance of axons during development and regeneration. We have proposed (Taniuchi et al., 1986b) that the appearance of NGF receptors on Schwann cells serves to sequester NGF on their cell surfaces, providing an NGF-laden substratum through which axons of NGF-dependent neurons grow (tropic guidance). As the axon reaches the Schwann cell, it is able to use the NGF in a trophic manner. This is plausible, since the affinity of NGF for the Schwann cell receptor $\left(10^{-9}-10^{-8} \mathrm{M}\right)$ is lower than that for the high-affinity neuronal receptor $\left(10^{-11}-10^{-10} \mathrm{M}\right.$ range). The source of NGF remains uncertain, although in vitro (Adler and Varon, 1981; Noble et al., 1984) and in vivo (Rush, 1984; Korsching et al., 1986) evidence suggests that glial cells supply the neurons with the trophic factor. Fibroblasts within the neural sheath are also candidates for the synthesis of NGF.

It is unclear whether NGF interacts with the Schwann cell NGF receptor in the same manner as with neuronal NGF re- ceptors. We have incubated primary Schwann cell cultures with both NGF and polyclonal anti-NGF antibodies and have observed no significant morphological effects on these cells. No morphological effects of NGF on Schwann cells have been reported in the literature. Whether distinct biochemical events are altered with such treatments remains to be elucidated. If no effects are seen, it would support the hypothesis that Schwann cells present NGF receptors on their cell surface (and possibly secrete NGF, which acts in a pseudo-autocrine fashion) solely for the support of the developing or regenerating axons. A tenet of this hypothesis would be that other neurotrophic factors and their receptors appear on Schwann cells to subserve similar tropic and trophic support for non-NGF-dependent neurons.

In summary, NGF receptors are present on freshly isolated Schwann cells from fetal or neonatal rat peripheral nerve. This indicates that developing Schwann cells bear NGF receptors in vivo. NGF receptor densities increase dramatically in culture in a manner similar to that seen after axotomy of peripheral nerve in vivo. This results from the loss of axonal contact, which acts to suppress NGF receptor, and presumably NGF, expression on Schwann cells. The receptor on Schwann cells seems to be similar to the type II, low-affinity receptors present on neurons and $\mathrm{PC} 12$ cells. ${ }^{125} \mathrm{I}-\mathrm{NGF}$ is rapidly dissociated from the cell surface of Schwann cells, and we found no evidence of internalization of ligand. The binding of NGF to Schwann cells displays unusual properties, with a large component of very low affinity binding. The results of this study are consistent with the idea that NGF is produced by Schwann cells and sequestered on the Schwann cell surface and that this phenomenon has a role in Schwann cell/neuron interaction during development and after nerve injury.

\section{References}

Adler, R., and S. Varon (1981) Neuritic guidance by nonneuronal cells of ganglionic origin. Dev. Biol. 86: 69-80.

Aguayo, A. J., M. Benfey, and S. David (1983) A potential for axonal regeneration in neurons of the adult mammalian nervous system. In Nervous System Regeneration, B. Haber, J. R. Perez-Polo, G. A Hashim, and A. M. G. Stella, eds., pp. 327-340, Alan R. Liss, New York.

Asbury, A. K. (1967) Schwann cell proliferation in developing mouse sciatic nerve. A radioautographic study. J. Cell Biol. 34: 735-743.

Asbury, A. K., and B. G. Arnason (1968) Experimental allergic neuritis: A radioautographic study. J. Neuropathol. Exp. Neurol. 27:581590.

Bjorklund, A., and U. Stenevi (1979) Regeneration of monoaminergic and cholinergic neurons in the mammalian central nervous system. Physiol. Rev. 59: 62-100.

Bocchini, V., and P. U. Angeletti (1969) The nerve growth factor: Purification as a 30,000-molecular-weight protein. Proc. Natl. Acad. Sci. USA 64: 787-794.

Brockes, J. P., K. L. Fields, and M. C. Raff (1979) Studies on cultured rat Schwann cells. I. Establishment of purified populations from cultures of peripheral nerve. Brain Res. 165: 105-118.

Buxser, S. E. L. Watson, and G. L. Johnson (1983) A comparison of binding properties and structure of NGF receptor on PC12 pheochromocytoma and A875 melanoma cells. J. Cell. Biochem. 2: 219233.

Buxser, S. E., P. Puma, and G. L. Johnson (1985) Purification and properties of the nerve growth factor receptor. Biochem. Actions Hormones 12: 433-456.

Carbonetto, S. T., and R. W. Stach (1982) Localization of nerve growth factor bound to neurons growing nerve fibers in culture. Dev. Brain Res. 3: 463-473.

Chandler, C. E., L. M. Parsons, M. Hosang, and E. M. Shooter (1984) A monoclonal antibody modulates the interaction of nerve growth factor with PCl 2 cells. J. Biol. Chem. 259: 6882-6889.

David, S., and A. J. Aguayo (1981) Axonal elongation into peripheral 
nervous system "bridges" after central nervous system injury in adult rats. Science 214: 931-933.

DiStefano, P. S., J. B. Schweitzer, M. Taniuchi, and E. M. Johnson, Jr. (1985) Selective destruction of nerve growth factor receptor-bearing cells in vitro using a hybrid toxin composed of ricin $A$ chain and a monoclonal antibody against the nerve growth factor receptor. J. Cell Biol. 101: 1107-1114.

Fabricant, R. N., J. E. DeLarco, and G. J. Todaro (1977) Nerve growth factor receptors on human melanoma cells in culture. Proc. Natl. Acad. Sci. USA 74: 565-569.

Fallon, J. R. (1985) Neurite guidance by non-neuronal cells in culture: Preferential outgrowth of peripheral neurites on glial as compared to nonglial cells surfaces. J. Neurosci. 5: 3169-3177.

Feldman, H. A. (1972) Mathematical theory of complex ligand-binding systems at equilibrium: Some methods for parameter fitting. Anal. Biochem. 48: 317-338.

Frazier, W. A., L. F. Boyd, and R. A. Bradshaw (1974) Properties of the specific binding of ${ }^{125}$ I-nerve growth factor to responsive peripheral neurons. J. Biol. Chem. 249: 5513-5519.

Friedlander, D. R., M. Grumet, and G. M. Edelman (1986) Nerve growth factor enhances expression of neuron-glia cell adhesion molecule in PC12 cells. J. Cell Biol, 102: 413-419.

Greene, L. A., and A. S. Tischler (1982) PCl2 pheochromocytoma cultures in neurobiological research. Adv. Cell Neurobiol. 3: 373414.

Guth, L. (1975) History of central nervous system regeneration research. Exp. Neurol. 48: 3-15.

Herrup, K., and H. Thoenen (1979) Properties of the nerve growth factor receptor of a clonal line of rat pheochromocytoma $\mathrm{PCl} 2$ cells. Exp. Cell Res. 121: 71-78.

Korsching, S. I., R. Heumann, A. Davies, and H. Thoenen (1986) Levels of nerve growth factor and its mRNA during development and regeneration of the peripheral nervous system. Soc. Neurosci. Abstr. 12: 1096.

Kromer, L. F., and C. J. Cornbrooks (1986) Transplants of Schwann cell cultures promote axonal regeneration in the adult mammalian brain. Proc. Natl. Acad. Sci. USA 82: 6330-6334.

Laemmli, U. K. (1970) Cleavage of structural proteins during the assembly of the head of bacteriophage T4. Nature 227: 680-685.

Manthorpe, M. E. Engvall, E. Rouslahti, F. M. Longo, G. E. Davis, and S. Varon (1983) Laminin promotes neuritic regeneration from cultured peripheral and central neurons. J. Cell Biol. 97: 1882-1890.

Marchalonis, J. J. (1969) An enzymic method for the trace iodination of immunoglobulins and other proteins. Biochem. J. 113: 299-305.

Moore, B. W. (1965) A soluble protein characteristic of the nervous system. Biochem. Biophys. Res. Commun. 19: 739-744.

Müller, H. W., M. J. Ignatius, D. H. Hangen, and E. M. Shooter (1986) Expression of specific sheath cell proteins during peripheral nerve growth and regeneration in mammals. J. Cell. Biol. 102: 393-402.

Noble, M., J. Fok-Seang, and J. Cohen (1984) Glia are a unique substrate for the in vitro growth of central nervous system neurons. J. Neurosci. 4: 1892-1903.

Olender, E. J., and R. W. Stach (1980) Sequestration of ${ }^{125}$ I-labeled nerve growth factor by sympathetic neurons. J. Biol. Chem. 255: 9338-9343.

Pleasure, D., B. Kreider, S. Shuman, and G. Sobue (1985) Tissue culture studies of Schwann cell proliferation and differentiation. Dev. Neurosci. 7: 364-373.

Raff, M. C., K. L. Fields, S.-I. Hakomori, R. Mirsky, R. M. Pruss, and J. Winter (1979) Cell-type-spccific markers for distinguishing and studying neurons and the major classes of glial cells in culture. Brain Res. 174: 283-308.
Rohrer, H. (1985) Nonneuronal cells from chick sympathetic and dorsal root sensory ganglia express catecholamine uptake and receptors for nerve growth factor during development. Dev. Biol. 111: 95107.

Ross, A. H., P. Grob, M. Bothwell, D. E. Elder, C. S. Ernst, N. Marano, B. F. D. Christ, C. C. Slemp, M. Herlyn, B. Atkinson, and H. Koprowski (1984) Characterization of nerve growth factor receptor in neural crest tumors using monoclonal antibodies. Proc. Natl. Acad. Sci. USA 81: 6681-6685.

Rush, R. A. (1984) Immunohistochemical localization of endogenous Nerve Growth Factor. Nature 312: 364-367.

Sanes, J. R. (1983) Roles of extracellular matrix in neural development. Annu. Rev. Physiol. 45: 581-600.

Schwab, M. E., and H. Thoenen (1985) Dissociated neurons regenerate into sciatic but not optic nerve explants in culture irrespective of neurotrophic factors. J. Neurosci. 5: 2415-2423.

Sherwin, S. A., J. D. Minna, A. F. Gazdar, and G. J. Todaro (1981) Expression of epidermal and nerve growth factor receptors and soft agar growth factor production by human lung cancer cells. Cancer Res. 41: 3538-3542.

Sonnenfeld, K. H., P. Bernd, G. Sobue, M. Lebwohl, and A. E. Rubenstein (1986) Nerve growth factor receptors on dissociated neurofibroma Schwann-like cells. Cancer Res. 46: 1446-1452.

Sutter, A., R. J. Riopelle, R. M. Harris-Warrick, and E. M. Shooter (1979a) The heterogeneity of nerve growth factor receptors. In Transmembrane Signaling (Prog. Clin. Biol. Res.), M. Bitensky, R. J. Collier, D. F. Steiner, and F. C. Fox, eds., pp. 659-667, Alan R. Liss, New York.

Sutter, A., R. J. Riopelle, R. M. Harris-Warrick, and E. M. Shooter (1979b) Nerve growth factor receptors: Characterization of two distinct classes of binding sites on chick embryo sensory ganglia cells. J. Biol. Chem. 254: 5972-5982.

Taniuchi, M., and E. M. Johnson, Jr. (1985) Characterization of the binding properties and retrograde axonal transport of a monoclonal antibody directed against the rat nerve growth factor receptor. J. Cell Biol. 101: 1100-1106.

Taniuchi, M., J. B. Schweitzer, and E. M. Johnson, Jr. (1986a) Nerve growth factor receptor molecules in rat brain. Proc. Natl. Acad. Sci. USA 83: 1950-1954.

Taniuchi, M., H. B. Clark, and E. M. Johnson, Jr. (1986b) Induction of nerve growth factor receptor in Schwann cells after axotomy. Proc. Natl. Acad. Sci. USA 83: 4094-4098.

Thoenen, H., and Y.-A. Barde (1980) Physiology of nerve growth factor. Physiol. Rev. 60: 1284-1335.

Thomas, G. A. (1948) Quantitative histology of Wallerian degeneration. II. Nuclear population in two nerves of different fibre spectrum. J. Anat. 82: 135-145.

Veraa, R. P., and B. Grafstein (1981) Cellular mechanisms for recovery from nervous system injury: A conference report. Exp. Neurol. 71 : 6-75.

Yan, Q., and E. M. Johnson, Jr. (1987) A quantitative study of the developmental expression of nerve growth factor (NGF) receptor in rats. Dev. Biol. 121: 139-148.

Yelton, D. E., C. Desaymard, and M. D. Scharff (1981) Use of monoclonal anti-mouse immunoglobulin to detect mouse antibodies. Hybridoma $1: 5-11$.

Zimmerman, A., and A. Sutter (1983) $\beta$-Nerve growth factor receptors on glial cells. Cell-cell interaction between neurones and Schwann cells in cultures of chick sensory ganglia. EMBO J. 2: 879-885. 